Хариенко С. Д.

Інститут технічної теплофізики НАН України. Україна, м. Київ

\title{
ОПІР ЗНОСУ ДЕТОНАЦІЙНИХ ПОКРИТТІВ Cr-Si-B В УМОВАХ ГРАНИЧНОГО ЗМАЩУВАННЯ
}

Розглянуто вплив елементоорганічних присадок на закономірності зношування покриттів. Установлено, що поблизу поверхні й у шарах, що безпосередньо межують із зовнішнім середовищем, енергетичні зміни призводять до значного підвищення термодинамічної стабільності поверхневого шару, за рахунок поверхневого насичення хімічно активними елементами присадок, що містяться в мастилах, а також внаслідок сегрегації вхідних до складу покриттів легуючих елементів у навантаженні тертям поверхневі шари покриттів. [dx.doi.org/10.29010/085.13]

Ключові слова: гетерогенні покриття; граничне тертя; присадки.

Вступ

Підвищення ефективності використання сучасної техніки являє сьогодні сукупність багатьох окремих проблем створення умов для забезпечення максимального використання іiі потенціальних можливостей. Одним із напрямів їх вирішення є застосування досягнень, які забезпечуються високоякісними технологіями і дозволяють 3 науковою обгрунтованістю та технікоекономічною цілеспрямованістю вирішувати питання ремонту і відновлення зношених деталей при забезпеченні в межах експлуатаційних режимів високого рівня надійності.

Одним із визначальних факторів працездатності та довговічності деталей, що працюють в умовах тертя, є стан мастильного середовища.

Граничне мащення для навантажених кінематичних пар - найбільш небезпечний і найменш вивчений розділ загальної проблеми мащення машин у зв'язку зі складністю охоплюваних нею абсорбційних, хемосорбційних і хімічних явищ в зоні фрикційного контакту [1;2].

\section{Мета роботи}

Розкриття закономірностей змащування гетерогенних покриттів на основі $\mathrm{Cr}$ та легованих $\mathrm{Si}$ i В при експлуатації в різних мастильних середовищах, з'ясування механізмів впливу поверхнево-активних речовин (ПАР) на інтенсивність зношування у широких навантажувально-швидкісних діапазонах та встановлення областей стійкого прояву ефекту структурної пристосованості.

\section{Методика досліджень}

Дослідження процесів тертя та зношування гетерогенних покриттів проводились у інактивному мастилі (вазелінове масло та мінеральне типу МС-20) з домішками ПАР. Випробування на знос здійснювали на універсальній машині тертя типу УМТ при регулярній подачі мастила в зону контактів зразків $(\mathrm{Dxd}=25 \times 17,5$ мм $)$. Товщина покриттів після доведення становила 0,20-0,22 мм, шорсткість поверхні $R_{a}=0,63-0,22$.

Зразки контртіла були виготовлені із широко використовуваних матеріалів типу 30ХГСА, 38 ХМЮА, сталі 45, в якості мастильних середовищ, як визначалось, використовували вазелінове масло, вазелінове з домішками ПАР ( $2 \%$ олеїнової кислоти), мінеральне масло МС-20 з наступним диференційованим введенням сірко-, хлоро- і фосфоровмісних присадок. Вибір інактивного мастильного середовища поряд з маслами, що містять ПАР i присадки, пов'язаний із з'ясуванням основних закономірностей механізмів зношування досліджуваних покриттів в умовах граничного тертя і визначенням впливу домішок на кінетику утворення вторинних структур із відновними властивостями.

\section{Результати досліджень}

Дослідження композиційного детонаційного покриття типу $\mathrm{Cr}-\mathrm{Si}-\mathrm{B}$ насамперед були пов'язані 3 визначенням його структурно-фазового стану. В таблиці 1 приведено зміну фізико-механічних властивостей в залежності від фазового складу.

Як видно, введення бору, як структурної складової композиційного покриття, значно покращує фізико- 


\section{технологические TC 4/2018}

СИСТЕМЫ IC

Таблиця 1

Зміна фізико-механічних властивостей від фазового складу

\begin{tabular}{|c|c|c|c|c|}
\hline Покриття & Товщина, мм & $\begin{array}{c}\text { Межа міцності до } \\
\text { руйнування, ГПа }\end{array}$ & $\begin{array}{c}\text { Міцність зчеплення з } \\
\text { основою, МПа }\end{array}$ & Мікротвердість, ГПа \\
\hline $\mathrm{Cr}-\mathrm{Si}$ & $0,16-0,20$ & $0,65-0,76$ & $50-83$ & $6,0-6,9$ \\
\hline $\mathrm{Cr}-\mathrm{Si}-\mathrm{B}$ & $0,11-0,20$ & $0,79-0,87$ & $78-108$ & $10,5-12,7$ \\
\hline
\end{tabular}

механічні властивості і збільшується межа міцності до руйнування, міцність зчеплення з основою та мікротвердістю. На наш погляд це обумовлено формуванням перш за все, тугоплавких боридних фаз $\mathrm{Cr}_{4} \mathrm{~B}$, $\mathrm{Cr}_{2} \mathrm{~B}, \mathrm{Cr}_{5} \mathrm{~B}_{3}, \mathrm{CrB}, \mathrm{Cr}_{3} \mathrm{~B}_{4}, \mathrm{CrB}_{2}$. Взаємодія хрому та кремнію призводить до утворення твердих зносостійких силіцидів хрому $\mathrm{CrSi}, \mathrm{Cr}_{2} \mathrm{Si}_{3}, \mathrm{CrSi}_{2}$. Рентгеноструктурний аналіз виявив також наявність твердих розчинів бору в хромі і кремнії та твердий розчин кремнію в хромі. Крім того, в структурі покриттів присутні оксиди хрому та кремнію, що утворюються при напиленні у повітрі. Рентгенофазовий і металографічний аналіз стану покриттів виявив, що характерною рисою мікроструктури є багатофазність і дрібнодисперсність. На рис. 1 зображено мікрофотографії структурних особливостей розподілу компонентів покриттів, які випробувались в умовах мащення.

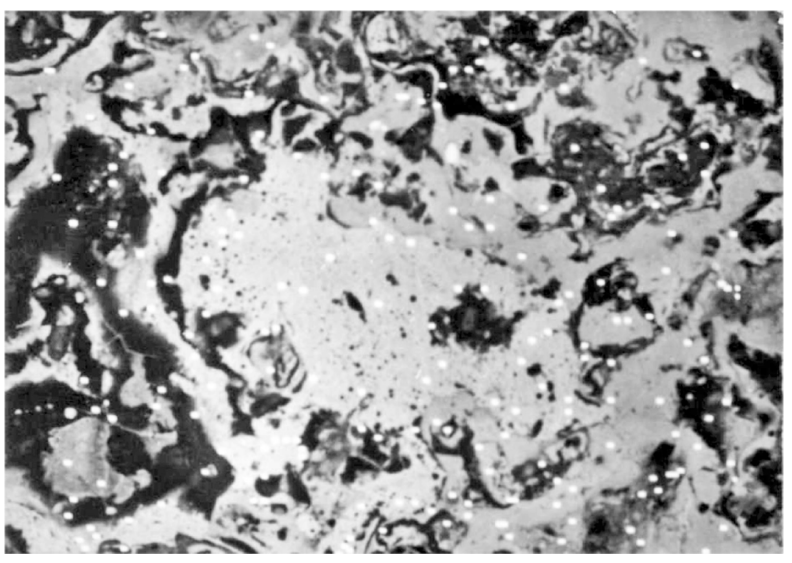

a)
Для підтвердження явища сегрегації легуючих елементів до поверхні тертя і одержання кількісної та якісної оцінки вмісту хрому і кремнію на поверхні тертя були проведені дослідження із застосуванням оже-спектроскопії. Проводився оже-спектральний аналіз поверхні тертя безпосередньо і після іонного травлення до глибини $5000 \AA$. Виявлено, що хімічний склад поверхні тертя і поверхневого шару значно відрізняється.

Крім сполук основного елемента, хрома, на поверхні тертя присутні кремній, кисень, фосфор, сірка, хлор і вуглець. Кількісний аналіз вмісту перелічених елементів на поверхні поданий в таблиці 2.

При пошаровому іонному травленні матеріалу з одночасним хімічним аналізом була встановлена закономірність розподілу елементів. Максимальний вміст хрому і кремнію виявлено у підповерхне-

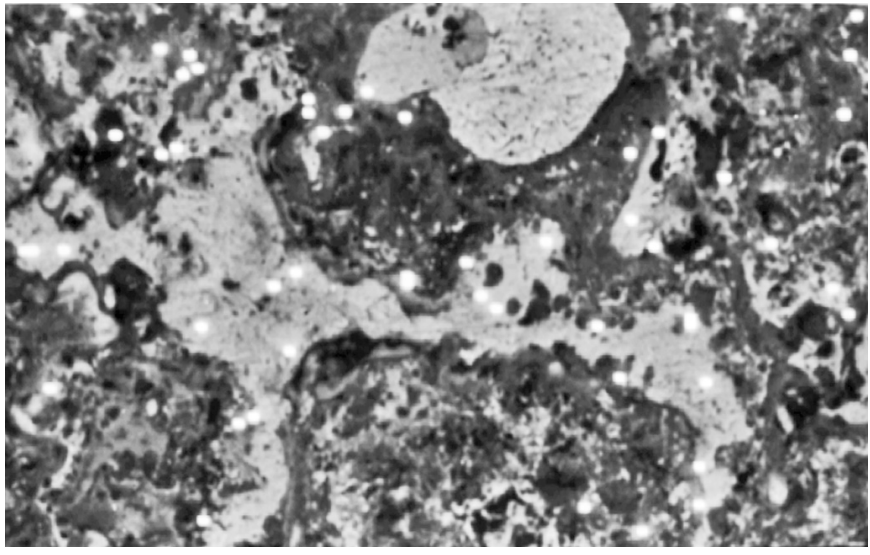

б)

Рис. 1. Мікрофотографії розподілу зон локалізації $\mathrm{Cr}(a)$, Si (б) в мікрооб’ємах поверхневого шару

Таблиця 2

Розподіл елементів на поверхні

\begin{tabular}{|c|c|c|c|}
\hline Елемент & Поверхня тертя, \% & Глибина 5000E, \% & Матриця матеріалу, \% \\
\hline $\mathrm{P}$ & 5,4 & 1,8 & - \\
\hline $\mathrm{S}$ & 6,4 & 1,4 & - \\
\hline $\mathrm{Cl}$ & 1,5 & 0,4 & - \\
\hline $\mathrm{C}$ & 4,9 & 0,3 & 4,3 \\
\hline $\mathrm{O}$ & 23,8 & 26,4 & 93,4 \\
\hline $\mathrm{Cr}$ & 40,9 & 47,3 & 12,3 \\
\hline $\mathrm{Si}$ & 17,2 & 22,3 & \\
\hline
\end{tabular}


вому шарі на глибині до 5000^̊. Подібним чином поводиться кисень, що дифундує в області сегрегації хрому і кремнію, утворюючи дифузійні ділянки, які складаються з оксидів.

У такий спосіб за допомогою оже-електронної спектроскопії проаналізовано розподіл вхідних до складу покриття легуючих елементів при роботі в мастильних середовищах, що містять фосфоро-, сірко-, хлоровмісні присадки. Проведений аналіз показав, що хром та кремній дифундують з об'єму матеріалу покриття до поверхневого і підповерхневого шару.

Розподіл кисню за глибиною покриття має той самий характер, що і розподіл хрому і кремнію. При цьому максимальний вміст фосфору, сірки, хлору переважно зареєстровано на поверхні тертя і швидко зменшується за глибиною травлення. Ці елементи дифундували з мастильного середовища, оскільки в матриці матеріалу реєстрували на рівні фону.

Наявність кисню в матриці пояснюється окисленням хрому і кремнію, що містяться в частках порошку, у процесі напилювання.

В якості мастильного середовища використовувалося чисте (неполярне) вазелінове масло і вазелінове масло з домішкою 2\% маси одноосновної ненасиченої олеїнової кислоти. Оптимальну концентрацію олеїнової кислоти визначали експериментально. Оцінку мастильних властивостей визначали за коефіцієнтом тертя. По мірі підвищення вмісту олеїнової кислоти до $2 \%$, коефіцієнт тертя, зменшуючись, досягає постійного рівня, на якому залишається стабільним до концентрації одноокисної кислоти, що відповідає майже 45\% маси. Таким чином, оптимальна концентрація кислоти у вазеліновому маслі, що відповідає мінімізації параметрів тертя, становить $2 \%$ маси. Крім того, для порівняння оптимальних результатів аналогічні пари тертя за тими ж програмами випробували в середовищі мінерального масла МС-20.

Результати дослідження зображені на рис. 2. При випробуванні покриттів у середовищі вазелі-

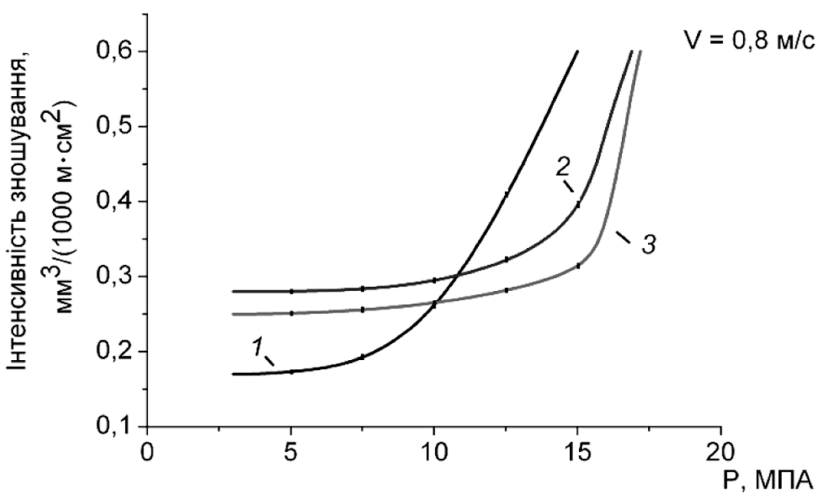

a) нового масла, у яких не міститься ПАР, спостерігається мінімальна величина зносу при максимальному коефіцієнті тертя.

При додаванні у вазелінове масло ПАР інтенсивність зношування збільшується майже в два рази при одночасному зниженні коефіцієнта тертя.

Діапазон нормального зношення по навантаженню при мастильній дії вазелінового масла порівняно невисокий і значно розширюється при введенні ПАР.

Помітне зниження коефіцієнта тертя і збільшення границі стійкості, що визначає діапазон експлуатації, пов’язано з хемосорбцією кисню на поверхні тертя й утворення захисних вторинних структур, а також із ефектом фізично адсорбованих ПАР, що обумовлюють пластифікування. При чому збільшення навантаження робить більш діючий вплив, ніж підвищення швидкості ковзання, що, виходячи з прояву ефекту Ребіндера, пов'язано з нерівномірно активованим станом поверхневого шару й орієнтацією структури в процесі тертя.

Вазелінове масло, що містить у своєму складі ПАР, що адсорбується на поверхнях деформованого при терті покриття, викликає адсорбційне пластифікування, тобто здатність до більш інтенсивної деформації у тонкому поверхневому шарі товщиною в частки мікрометра. При цьому ПАР полегшують вихід дислокацій до поверхні деформованого покриття, що зменшує внутрішні напруження i запобігає поширенню деформації вглиб зразків.

Для аналізу процесів важливим є розподіл мікротвердості від поверхні тертя по глибині деформованого шару. На рис. 3 подано результати виміру мікротвердості.

При роботі у вазеліновому маслі мікротвердість поверхневого шару підвищується незначно $(\mathrm{H} \mu=5880 \mathrm{MПа),} \mathrm{глибина} \mathrm{деформованої} \mathrm{зони}$ досягає $h=1,78$ мкм. Додавання у вазелінове масло ПАР істотно підвищує мікротвердість поверхні тертя (Н $\mu=14500$ МПа) при одночасно-

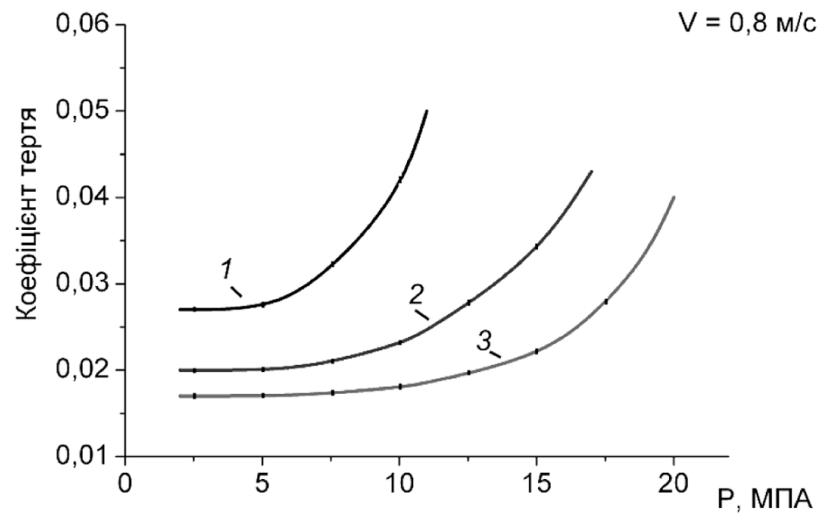

б)

Рис. 2. Зміна інтенсивності зношування ( $a)$ і коефіцієнта тертя (б) залежно від питомого навантаження ( $V=0,8$ м/с): 1 - у середовищі вазелінового масла; 2 - у середовищі вазелінового масла з ПАР; 3 - у середовищі мінерального масла МС-20 


\section{$\mathrm{v=0,8 \textrm {mc }}$}
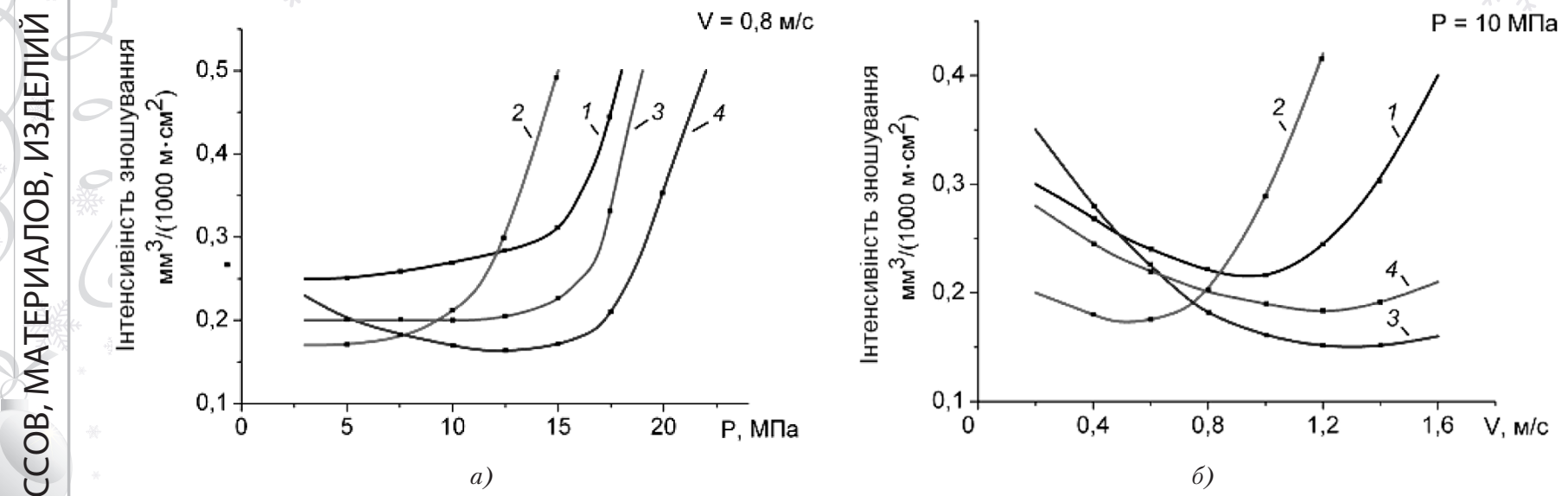

Рис. 3. Зміна інтенсивності зношування покриттів від питомого навантаження при $V=0,8$ м/с $(a)$ і швидкості при $P=10$ МПа: 1 - у середовищі масла МC-20; 2 - у середовищі масла МC-20+P; 3 - у середовищі масла MC-20+S; 4 - у середовищі масла MC-20+Cl

му зменшенні глибини деформованого шару $(\mathrm{H} \mu=14500 \mathrm{MПа})$. Крива, що отримана під час тертя в середовищі мінерального масла МС-20, займає проміжне положення. Ступінь виникаючого наклепу при деформації поверхні покриття значно зростає в присутності ПАР, тобто підвищується мікротвердість наклепаного шару, що істотно впливає на противнозношувальні властивості покриття і сприяє збільшенню межі текучості матеріалу поверхневого шару, відповідно розширенню діапазону нормального зношування як за навантаженням, так і за швидкістю ковзання. Це відбувається при зовнішньому ефекті Ребіндера, що виявляється при роботі покриттів у середовищі, яке містить ПАР.

У першу чергу, цим пояснюється значне збільшення навантажувально-швидкісного діапазону роботи покриття в порівнянні з мастильним середовищем, що не містять ПАР. Однак наявність ПАР під час тертя детонаційних покриттів викликає небажані конкуруючі процеси. Так, одночасно із зовнішнім ефектом виявляється внутрішній ефект [3], який відбувається в процесі адсорбції ПАР.

Зворотна залежність спостерігалась при вимірюванні коефіцієнта тертя. Максимальне значення коефіцієнта відповідає вазеліновому маслу, мінімальне - мінеральному, що в першу чергу, пояснюється не тільки наявністю в мінеральному маслі ПАР, але і його підвищеною адсорбцією до поверхні тертя за рахунок більш високої кінетичної в’язкості.

Як виявили експериментальні дослідження, ПАР значно впливають на процеси тертя та зношування покриттів. При відсутності в маслі ПАР спостерігається мінімальний знос при незначному навантажувально-швидкісному діапазоні і високому коефіцієнті тертя.

Додавання в мастила ПАР значно розширює експлуатаційні можливості покриттів. Використовуючи отримані результати про дію внутрішнього і зовнішнього ефектів Ребіндера в процесі гранично- го мащення, можна припустити такий механізм зношування детонаційних покриттів за наявності мастильного середовища. У процесі контактної взаємодії не тільки деформуються поверхневі шари, зерна, але і змінюється їня орієнтація, тобто має місце текстурування. Іншими словами, поверхня тертя пристосовується до діючої схеми механічних напруг.

Якщо напруга при терті не перевищує межі текучості матеріалу, які залежить від розміру осередків, відбувається нормальне зношування.

Якщо напруга під час тертя стає більше межі текучості матеріалу, відбувається руйнування. При цьому стінки осередків, орієнтованих перпендикулярно напрямку тертя, ініціюють початок руйнування, оскільки є концентраторами напруг і джерелами мікротріщин.

Одночасно при роботі такого матеріалу, як гетерогенне покриття, що містить тугоплавкі фази, буде відбуватися утворення мікропорожнеч у підповерхневому шарі, а наявність незначної пористості в матеріалі при одночасній дії внутрішнього ефекту Ребіндера сприяє розкриттю порожнеч i утворенню мікротріщин, що призводить до утворення часточок зносу.

Отже, під час тертя гетерогенних покриттів за наявності мастильного середовища важливу роль буде відігравати ПАР у маслі, що обумовлюють прояв різних видів ефекту Ребіндера і визначають механізм зношування матеріалу.

При проведенні дослідів щодо визначення ступеня впливу елемента органічних присадок на процеси тертя і зношування покриттів, як базовим було обрано мінеральне масло МС-20, в яке диференційовано додавалися елементоорганічні присадки: фосфоровмісні - трикрезилфосфат, сірковмісні - вільна сірка; хлоровмісні - хлористий бензол.

Вміст вільної сірки в маслі дорівнював 0,25\% маси, фосфору і хлору - до 1 \% маси. Можливість застосування зазначених вище присадок при 
мащенні гетерогенних покриттів потребує детального вивчення.

Як показали проведені дослідження (рис. 3), органічні сполуки фосфору, сірки і хлору мають високі антизадирні і протиспрацьовувальні властивості і здатні утворювати на поверхнях тертя гетерогенних покриттів вторинні структури, що захищають від зносу і схоплювання.

При мащенні поверхонь тертя гетерогенного покриття системи $\mathrm{Cr}-\mathrm{Si}-\mathrm{B}$ найбільш ефективна сірковмісна присадка (рис. 3, крива 3), оскільки вона забезпечує широкий діапазон нормального зношування незначної інтенсивності.

Сірковмісна присадка створює на поверхні тертя покриття плівки сульфідів (установити точно фазовий склад вторинних структур не вдалося через незначну товщину), що відрізняються досить високою твердістю, міцністю і температурою плавлення. Однак тверді плівки сульфідів мають значний опір зрушенню, що обумовлює більш високий коефіцієнт тертя (рис. 3) у порівнянні з іншими присадками.

Оскільки сульфіди утворюються при більш високих температурах у порівнянні з іншими присадками [4; 5], позитивні ефекти під час граничного тертя виявляються тільки при високих навантаженнях і швидкостях ковзання, коли температура в зоні фрикційного контакту значно зростає (рис. 3, крива 3). При незначних навантаженнях і швидкостях ковзання застосування сірковмісних присадок неефективно.

Зворотний ефект щодо інтенсивності зношування, коефіцієнта тертя і діапазону нормального зношування має фосфоровмісна присадка (рис. 6, крива 2).

Фосфоровмісна присадка ефективна при незначних навантаженнях i швидкостях ковзання. Отже, фосфор починає реагувати 3 поверхнею тертя детонаційного покриття при низьких температурах, утворюючи при цьому ефективні плівки вторинних структур, які мають високу рухливість, здатність до самовідновлення дефектів на поверхні тертя і створення шаруватої структури. Ці плівки, як показали дослідження, на легких режимах тертя мають високі протиспрацьовувальні властивості і забезпечують досить низькі коефіцієнти тертя. Однак при збільшенні навантаження чи швидкості ковзання спостерігається значне підвищення температури у вузлах тертя.

3 аналізу отриманих результатів випливає, що при роботі в мастильних середовищах різні елементоорганічні присадки, хімічно активні елементи, такі, як фосфор, сірка. дифундують у поверхневий шар, тим самим значно знижують поверхневу енергію, сприяючи створенню захисних вторинних структур, що позитивно впливає на процес тертя.
Великий відсоток вмісту даних елементів спостерігається на поверхні покриттів (фосфору 7,4\%; сірки - 6,4 \%; хлору - 6,2 \%) і різко зменшується за глибиною. Проведені раніше дослідження дозволяють припустити, що сегрегація таких елементів, як фосфор, сірка, хлор, вуглець, дифундувавши 3 мастильного середовища, призводить до утворення в поверхневих шарах покриття евтектики з низькою температурою перетворення, тобто до умов, коли фазові перетворення спостерігаються при порівняно низьких температурах.

\section{Висновки}

У поверхневому шарі відбуваються зміни хімічного складу, структури і властивостей, що виникають у процесі дисипації механічної енергії навантажених тертям покриттів. При цьому основним явищем, що контролює ці зміни, виступає дифузія хімічно активних елементів з мастильних середовищ i їх трибохімічна взаємодія. Отже, поблизу поверхні й у шарах, що безпосередньо межують із зовнішнім середовищем, енергетичні зміни призводять до значного підвищення термодинамічної стабільності поверхневого шару, по-перше, за рахунок поверхневого насичення хімічно активними елементами присадок, що містяться в мастилах, подруге, внаслідок сегрегації вхідних до складу покриттів легуючих елементів у навантаженні тертям поверхневі шари покриттів. Зменшення вільної поверхневої енергії пов'язано з анігіляцією вакансії в поверхневому шарі, наслідком чого є більш повна реалізація сил міжатомних зв'язків, що, у свою чергу, збільшує опір пластичної деформації i, таким чином, сприяє розширенню діапазону структурної пристосованості покриттів у даних умовах тертя, тобто в режимі межового мащення насичення хімічно активними домішками, що беруть участь у терті покриттів, дозволяє змінювати структурно-фазовий стан поверхневого шару i забезпечити тим самим тривалу стабільність і триботехнічну зносостійкість їхньої структури в процесі експлуатації.

\section{Лiтература}

[1] Машков Ю. А. Трибология конструкционных материалов/ Ю. А. Машков // Омск.: ОмГТУ. - 2001 C. 299.

[2] УсачевВ.В. Смазочные материалы с добавками / В.В.Усачев, Л.И. Погодаев // Проблемы машиностроения и надёжности машин. - 2009. - №3/4. C. 63-68.

[3] Ляшенко Б.А. Анализ состояния, тенденции развития и рекомендации по применению защитных покрытий / Б.А.Ляшенко, Н.А.Зенкин, Б.Ф.Пипа и др. // - К.: ГАЛПУ. - 1999. - С. 49. 
[4] Щепетов В.В. Износостойкость детонационных покрытий из порошков $\mathrm{Ni}-\mathrm{Al}-\mathrm{Si}, \mathrm{Ni}-\mathrm{Al}-\mathrm{B}$ в условиях граничной смазки / В.В Щепетов., В.Х. Кадыров // Порошковая металлургия. - 1989. - №11. - С. 7477.
[5] Ребиндер П.А. Влияние активных смазочных сред на деформирование сопряженных поверхностей трения / П.А. Ребиндер // - В.: О природе трения твердых тел. - 1971.

\section{Kharchenko S. D.}

Institute of Engineering Thermophysics of NAS of Ukraine. Ukraine, Kyiv

\section{WEAR RESISTANCE WITH DETONATION COATINGS Cr-Si-B IN CONDITIONS OF BOUNDARY LUBRICATION}

The influence of the organometallic compounds additives on regularities coatings wear is considered. It is established that near the surface and in layers, which are directly adjacent to the external environment, energy changes lead to a significant increase in the thermodynamic stability of the surface layer.

Changes in the surface layer occur due to surface saturation chemically active elements of additives contained in oils, and also because of the segregation of incoming coatings alloying elements in the loading of friction superficial layers of coatings. [dx.doi.org/10.29010/085.13]

Keywords: heterogeneous coatings; friction of boundary lubrication; additives.

\section{References}

[1] Radchenko S. Gh. Sustainable methods of evaluation statistical models / S.Gh.Radchenko // K.:PP «1. Mashkov Yu. Tribology of construction materials / Omsk. - 2001 - p. 299.

[2] Usachev V. Lubricants with additives / Problems of mechanical engineering and machine reliability. - 2009. - № 3/4. p. 6368 .

[3] Lyashenko B. Analysis of the state, development trends and recommendations on the use of protective coatings / K. 1999. - P. 49.

[4] Shchepetov V. Wear resistance of detonation coatings from powders Ni-Al-Si, Ni-Al-B in the conditions of boundary lubrication // Powder metallurgy. - 1989. - №11. - p. 7477.

[5] Rebinder, P., Effect of active lubricants on the deformation of conjugate friction surfaces / On the nature of friction of solids. - 1971 